\title{
A TEMPEST IN A TEAPOT? NINETEENTH-CENTURY CONTESTS FOR LAND IN SOUTH AFRICA'S CALEDON VALLEY AND THE INVENTION OF THE MFECANE
}

\begin{abstract}
The unresolved debate on the mfecane in Southern African history has been marked by general acceptance of the proposition that large scale loss of life and disruption of settled society was experienced across the whole region. Attempts to quantify either the violence or mortality have been stymied by a lack of evidence. What apparently reliable evidence does exist describes small districts, most notably the Caledon Valley. In contrast to Julian Cobbing, who called the mfecane an alibi for colonial-sponsored violence, this article argues that much documentation of conflict in the Caledon region consisted of various 'alibis' for African land seizures and claims in the 1840 s and ' 50 s.
\end{abstract}

KEY WORDS: pre-colonial, mfecane, Lesotho, South Africa, nineteenthcentury, warfare, land

A hotly contested issue in the debate on South Africa's mfecane which enlivened the pages of this journal a decade ago was the charge that colonial historians invented the concept as part of a continuing campaign to absolve settler capitalism from responsibility for violent convulsions in South- 
Eastern Africa in the first half of the nineteenth century. ${ }^{i}$ This article takes a different tack by arguing that African struggles for land and power in the period 1833-54 played a decisive role in developing the mfecane concept. The self-serving narratives devised by African rivals and their missionary clients in and around the emerging kingdom of Lesotho set the pattern for future accounts and were responsible for introducing the word lifaqane into historical discourse long before the word mfecane first appeared in print.

\section{THE MFECANE DEBATE}

It may be worthwhile to begin by summarising the main points at issue in the mfecane debate launched in JAH by Julian Cobbing in 1988 because it subsided without reaching definite conclusions. A major conference held in 1991 produced a landmark publication, The Mfecane Aftermath in 1995, but failed to answer all the questions he had raised. ${ }^{\text {ii }}$ This was partly due to Cobbing's regrettable withdrawal from the project and partly due to the vague manner in which the issues requiring resolution were framed. Cobbing contributed to the confusion by his own tendency to bundle everything into a single package.iii His position may be roughly summarised as follows. An upsurge in the coastal slave trade from Port Natal to Inhambane from the beginning of the nineteenth century caused Africans to turn to larger states for defence at the very time when demands for labour on 
the Eastern frontier of the Cape Colony were stimulating destructive raiding by bands of armed horsemen (Griqua and Kora) and state-sponsored warfare against the Xhosa chiefs. Europeans implicated in these activities tried to cover up their involvement by asserting that Africans were the sole instigators of violence. Later historians perpetuated the original cover-up through their invention of the mfecane.

Although Cobbing clearly wishes to maintain this account as a package, its elements can be disaggregated into a series of discrete questions:

- Did widespread violent conflict engulf all South-Eastern Africa in the 1820s?

- Does the word mfecane represent African recollections of a period of unusual violence and suffering, or is it a scholarly construction?

- Did an upsurge in slave trading on the Mozambique coast stimulate the formation of the Zulu and other large states in the opening decades of the nineteenth century?

- How much documented conflict stemmed from the rise of the Zulu kingdom?

- How much documented conflict can be attributed to raids by horsemen with firearms on the western highveld?

- How much documented conflict stemmed from colonial demands for farm labour on the Eastern Cape frontier? 
Cobbing won on many points. The word mfecane has been shown to be a scholarly construction - popularised by Eric Walker's 1928 History of South Africa - not an African communal memory. Few if any historians would now wish to defend John Omer-Cooper's influential argument that the rise of the Zulu kingdom began a chain reaction of violence. It can be demonstrated that the campaigns of Sebetwane and Molitsane against the Hurutshe, Tlhaping and Ngwaketse in 1822 were launched before Mpangazita's Hlubi and Matiwane's Ngwane groups crossed the Drakensberg; they could not therefore have been caused by any activity of the Zulu. Cobbing's argument that Griqua/Kora raiding for cattle and children was an independent cause of disruption to chieftaincies in the western highveld seems also to have been accepted. ${ }^{\text {iv }}$ On the other hand, his argument that an upsurge in demand for slaves on the coast stimulated the growth of 'defensive formations' such as the Zulu, Swazi and Ndwandwe kingdoms won little support because the upsurge in slaving after the wars of the French Revolution in 1815 came too late to explain the appearance of such elaborately constructed states.

Throughout the debate one key assumption went unquestioned by all parties: that a wave of exceptional violence accompanied by huge losses of life did sweep across all the uncolonised regions of Southeast and Central Africa in the early nineteenth century disrupting a previous equilibrium. Cobbing himself accepted the proposition. He differed from earlier 
historians only in his attribution of that violence to disturbing forces emanating from the Cape Colony and east-coast slaving. This caused much confusion in the early stages of the debate. Some contributors to the 1991 conference in Johannesburg devoted their presentations to proving that there really was 'mfecane' distress in particular places.v Gradually it became clear that Cobbing had not denied a wave of violence when he said there was no mfecane. What he had challenged was the idea of the mfecane as a special epoch of purely African-initiated violence which spread by chain reaction following the rise of the Zulu monarchy. As one scholar quipped, he did not remove the arrows from the historians' mfecane maps; he drew different arrows. vi This article begins by asking how do we know that a wave of violence engulfed the region? It concludes that evidence is slim or nonexistent. Scholars have been extremely vague in their attempts to define the extent, loss of life and duration of the so-called mfecane. Even in the valley of the Caledon River (which marks the northern boundary between Lesotho and South Africa) where so much of the documented conflict allegedly occurred, evidence is tainted by the wishful thinking of missionaries and the self-interest of local chiefs who were pursuing recognition of competing land claims in the period 1845-54.

\section{DIFFICULTIES OF GUAGING THE EXTENT OF VIOLENCE AND} POPULATION LOSS 
Vagueness of geographical definition pervaded discussions from the beginning. George McCall Theal made a notorious attempt to specify the territory affected by extraordinary violence with a map published in the 1891 edition of his History of South Africa, 1795-1834 which purported to show 'territory almost depopulated by the Zulu wars before 1834 '.vii It included half the future Orange Free State, all of the Transvaal and Natal, SouthEastern Botswana, and Southern Zimbabwe. Eric Walker in 1928 simply observed that 'pandemonium had raged' among the Bantu of South-Eastern Africa'. The whole South-Eastern interior was a 'whirling mass of tribesmen.'viii The vagueness survived several historiographical revolutions. Though Africanist history succeeded colonialist history in the 1960s, maps still depicted the region of mfecane violence as a cross-hatched blotch extending indefinitely eastward from the western highveld. ${ }^{\text {ix }}$ John OmerCooper vastly extended the geographical scope of the concept in 1966 by presenting the movement of several Sotho and Nguni bands into central and interlacustrine Africa as part and parcel of the mfecane. ${ }^{x}$ This had the effect of extending the chronological life of the mfecane well into the 1850s, doubling the 'fifteen years or so' Walker had estimated. Others conceived the mfecane not as a period but a wave or storm which passed over different regions at different periods: 'the direful war-wave first set in motion by the insatiable ambition of the great Zulu conqueror ... rolled onward ...until it 
reached the far interior, affecting every nation with which it came in contact'; 'by 1825 the Difaqane had passed beyond the Southern Sotho, but it continued to plague the Tswana for another few years'; 'the maelstrom of the 1820s, generally known as the Mfecane, had reduced the tribes throughout central South Africa to chaos'. ${ }^{x i}$

Even more uncertainty pervades discussions of loss of life. Natal trader Henry Francis Fynn told Samuel Charters in 1838 that 'not less than 1,000,000 human beings were destroyed' by Shaka, the Zulu king.xii Theal extrapolated from this and other uncertain reports from the highveld to reach a total 'nearer two millions', telling readers that 'compared with this, the total loss of human life, occasioned by all the wars in South Africa in which Europeans have engaged since first they set foot in the country, sinks into insignificance'. ${ }^{\text {xiii }}$ The former missionary D. F. Ellenberger offered a macabre subtotal of deaths due to cannibalism in the region bounded by the Drakensberg mountains and the Vaal and Orange rivers.

Let us estimate the number of cannibals at a minimum, say 4,000. Say each one ate one person a month, and we arrive at the total of 48,000 persons eaten during one year; and during the six worst years, between 1822 and 1828, at the appalling figure of 288,000 devoured by their fellows. If we allow for those eaten during subsequent years, it is easy to arrive at a total of 300,000 . xiv 
Although subsequent historians ventured to suggest that the numbers of deaths had been greatly exaggerated, the label 'holocaust' was still being applied to the mfecane by respected scholars in the 1980s. ${ }^{x v}$ The impression of a monumental genocide was spread to a much larger audience when Hannah Arendt's influential Origins of Totalitarianism repeated the figure of one million dead as a result of Shaka's wars. ${ }^{x v i}$ The acceptance of such large round figures on the basis of so little proffered evidence has led literary critic and historian Dan Wylie to observe that the mfecane 'is fundamentally, and essentially no more than a rhetorical construction - or, more accurately, an abstraction arising from a rhetorics of violence'.xvii What substratum of hard evidence exists to show how much territory was swept by unusual violence, how long the period of special violence continued and how many people died? The answer seems to be remarkably little.

In the first place, it seems impossible to prove that any previous state of peace and equilibrium existed in any part of South-Eastern Africa from the Zambezi to the KwaZulu-Natal Coast before the supposed outbreak of the mfecane in the 1820s. A colonial newspaper editor in the late 1830s bemoaned the loss of life caused by Britain's failure to annex Natal before Shaka commenced his savage career.

Happy would it have been for the Aborigines of the country, had this right [of the British to Natal] not been suffered to lie dormant. What, 
we ask, has become of the tribes, which once occupied the fertile country where the emigrants now are? Where are all those thousands of inhabitants which once dwelt in the 'fenced cities,' visited only 20 years ago by the missionary Campbell? All, all are swept away, as by 'the besom of destruction!' the country has reverted to an unproductive wilderness - its former populousness is only known as matter of history, or inferred, from the signs of former cultivation, and especially from the human bones which lie so profusely scattered over the whole surface of the land. Since the Cape has been a British possession not less than 1,000,000 human beings around have perished by their own intestine feuds. xviii

This passage deliberately twists the reports of John Campbell, the missionary who had been sent to South Africa in 1814 and 1820 to inspect the operations of the London Missionary Society. True, he had reported large fenced towns, but he certainly had not depicted a society at peace. He called the whole region a 'land of strife and blood'. xix He met chiefs who had lost many sons in battle in raids against distant enemies. He was told that chiefs located their headquarters on hills 'because of enemies' and that Makkaba, 'king of the Wanketzens ... greatly lessened' the population of the Hurutshe by continual raiding'. Campbell learned that north of the Harutshe territory near the headwaters of the Limpopo 'there was no end to nations' who 'had 
nothing else to do but to kill one another'. He found many areas marked by abandoned stone ruins deserted for no apparent reason. All of this evidence was hearsay or inferential - Campbell witnessed no warfare - but it was certainly at odds with the colonial editor's distorted account of the narrative as proof of a time of peace and plenty preceding the rise of Shaka. The missionary had a vested interest in propagating a narrative in which the coming of the gospel restores peace to a lost Eden; he supported it throughout his text with alleged examples of the beneficent missionary presence. That bias does not destroy the usefulness of the evidence of conflict Campbell had collected from living people. Neil Parsons, for example, has used it to suggest the outbreak of eighteenth-century 'trade wars'.xx However, it is clearly at odds with the picture of a tranquil premfecane equilibrium reigning along the corridor of springs stretching from the middle Orange River north to Southern Botswana. So are the reports of Campbell's subordinate agent, Robert Moffat, and Rolong historians of a large and warlike state built by Tau, 'the lion king', between Kuruman and the Molopo River in the middle decades of the eighteenth century. Tau gained a fearsome reputation as a warrior-king, 'conquering, dispersing, destroying and subjugating, until his name was a terror for miles around' the earliest chief in all Southern Africa to be remembered for 'hurling the victims of his justice over a precipice'.xxi 
Knowledge of conditions in a broad swath of territory extending from the Magaliesberg range east to the Mozambique coast before 1820 is slight or non-existent. On the basis of oral testimony collected decades later historians have guessed that the chieftaincy later known as the Pedi kingdom grew substantially in the late-eighteenth century under the leadership of Mampuru and Thulare (d. 1820). It was said that Thulare had raided for cattle as far west as the modern district of Rustenburg in the Magaliesberg.xxii The state of society in the territory lying between Pedi country on the Drakensberg escarpment and the Limpopo is quite unknown. Trade routes evidently criss-crossed the region but trade is by no means incompatible with conflict, as the experience of the north-western region demonstrates. French missionaries arriving in the Caledon Valley in the 1830s met visitors from Pedi country who, it seemed, had long been in communication with local people. They also collected dubious evidence indicating that cannibals had been active among the Pedi in the eighteenth century.xxiii

Of the state of society north to the Limpopo, nothing is known, as the historical record is silent. In contrast, the Mozambique coast has a long documented history of conflict before the nineteenth century. In 1721, Dutch visitors were told that chiefs involved in the slave trade would only exchange captives for guns. ${ }^{x i v}$ Further south, collisions between Xhosa chiefs and trekboers had become endemic by the end of the eighteenth 
century. In short, the picture of a primordial peace pervading South-Eastern Africa before the rise of the Zulu kingdom cannot be sustained in the face of a large body of contrary documentary and oral evidence.

With respect to violence after 1820, variations on a narrative of chain reactions pervade the historical record. One of the first printed versions appears in Joseph M. Orpen's History of the Basutus of South Africa (1857).

After about 1818, convulsions produced by Chaka [Shaka], which shook all South Africa, commenced, and dislodged the Amanguani [AmaNgwane] Zooloos under Matoana [Matiwane], the Amatluibi [AmaHlubi] Fingoes under Pacarita [Mpangazitha], from the district of Natal and the Mantatees from Harrismith; all these fell promiscuously upon the Basutus like a deluge, while they were disunited, attacking them and each other for years, without intermission, while Moselikatse, flying also from Dingaan, ravaged the country to the north, and almost exterminated the Bataungs, Molitsane's tribe. Pacarita was conquered by Matoana, and bequethed his sons and tribe to Moshesh [Moshweshwe]. Moshesh conquered Matoana, killing his principal general with his own hand, and drove him upon the Tambookies [Thembu], who, being assisted by the boers and troops under Major Dundas, routed him with great slaughter and drove him back upon Moshesh, by whose permission 
he passed back to Natal, leaving his wife and children and some of his people with Moshesh. $x x v$

A shorter version of the same sequence appears in the French missionary Eugène Casalis's The Basutos or Twenty-Three Years in South Africa. ${ }^{x \mathrm{x} i}$ A more lurid account written in about 1879 by Orpen's friend, George Stow, recounted how

Tshaka ... burst upon Matoane [Matiwane]; Matoane, in his turn, was thrust upon Pakarita [Mpangazitha] ; - Pakarita fled, and, in his flight, rushed upon the Batlokua [BaTlowkwa], under the queen-regent $\underline{\mathrm{Ma}}$ Intatesé [MaNthathisi], and her young son Sinkoneila [Sekonyela]; these, in their turn, fled before the pitiless storm, falling upon Tghlalelem [?], Enkokoto [?], and the Basia [BaSia\}, the people of MaNtathisi's father] tribes that were in the advance. A general war of the whole of the tribes followed this onslaught.xxvii

More or less the same sequence is repeated in most twentieth-century works. ${ }^{x x v i i}$ To this story, other chain-reaction sequences of violence have been attached. Most accounts of the western highveld, even before Cobbing's revisionist enterprise, admitted that raiding by Griqua, Hartenaar and Kora horsemen added to the general carnage. The clash of thousands of 
emaciated people with Tlhaping and Griqua forces at the so-called 'battle of Dithakong' near Kuruman in June 1823 and attacks on the Hurutshe and Ngwaketse chiefs in the same year have conventionally been viewed as consequences of conflict on the Caledon and Wilge river systems. The movements of Mzilikazi, Sobhuza and other chiefs away from the Ngunispeaking regions were treated by Omer-Cooper and others as analogous to the flight of the Hlubi and Ngwane into the Caledon. Though there have never been credible estimates of lives lost, it has been assumed that deaths, whether caused directly by armed conflict or by disruptions to food supply and dislocation, must have been enormous. This can be neither confirmed nor denied on the basis of available evidence. In respect to regions beyond the purview of eyewitnesses it is simply impossible to calculate mortality. Sekwati's Pedi appear to have lost many cattle to unidentifiable Nguni forces passing through their territory in the early 1820s but no accounting of human losses has been attempted. The missionary Robert Moffat, who first visited Mzilikazi in 1829, blamed the Ndebele king for the many deserted villages he saw along his route through the Magaliesberg ranges, but he was in no position to establish that any loss of life had accompanied the departure of the former population. ${ }^{x i x}$ Elsewhere - along the path taken by Sebetwane's Kololo to Barotseland, and in Mozambique, which was the initial destination of various 'Ngoni' warbands - the historical record is silent on mortality. The diary of Louis Tregardt, the Boer renegade who led 
the first trek across the northern highhveld to Mozambique reports people everywhere.xxx Thus, anyone seeking to estimate the demographic consequences of warfare in the 1820s is driven back to the little world of the Caledon Valley where evidence is most plentiful.

\section{THE PARADOX OF CALEDON VALLEY DEMOGRAPHY}

It is difficult to reconcile that evidence with the Difaqane legend. According to the legend, during the 1820s Jan Bloem, Barend Barends, Piet Witbooi, Gert Taaibosch and other mounted Griqua/Kora raiders devastated the lower Caledon while the murderous forces of Mpanganzitha's Hlubi and Matiwane's Ngwane were driving desperate people to cannibalism in the upper reaches of the same valley. As thousands, perhaps tens of thousands of people were dying in battle, others perished at the hands of cannibals as food ran short. Only those huddled for protection in the mountain fortresses of Sekonyela and Moshweshwe survived those perilous times. The worstcase scenarios calculated three hundred thousand dead in the lands lying between the Vaal and Orange rivers in the years 1822-28. Yet when missionaries and agents of the British government began visiting the region in 1833-35, they found nothing resembling the desolated landscape suggested by the legend. They found a numerous population living in peace 
and prosperity. Travellers' estimates of the inhabitants range from Arbousset and Daumas' guess of 45,000 made in 1836 to Gideon Joubert's guess of 150,000 made ten years later. ${ }^{x \times x}$ As Arbousset and Daumas had calculated the maximum carrying capacity of the region to be 150,000 , it is within the realms of possibility that no significant population loss had occurred. More remarkable still, most of the leading characters in the legendary period of conflict were still living in the vicinity. MaNthatisi was there. So were Machobane and his son Moshweshwe. Surprisingly, Nzwane alias David Danster, the Xhosa chief turned raider who was said to have brought the first gun into the region, was also living out a peaceful old age. Sekonyela, son of MaNthatisi, thrived, more powerful than ever - reviled by missionaries but still adept at attracting followers. Scattered among his people and in other parts of the valley were remnants of the Hlubi and Ngwane groups who had followed Mpanganzitha and Matiwane to glory and catastrophe. One of Matiwane's widows still lived under Moshweshwe's protection. ${ }^{x x x i i}$ Mpanganzitha's son, Mehlomakhulu, had pledged his allegiance to Sekonyela. ${ }^{x x \text { xii }}$ Barend Barends, ancient kingpin of the western highveld, had moved to the village of Lishuani, though Pieter Davids now commanded the remnants of his following, people still happy to be known as Bastards.xxxiv A trio of the Kora leaders - Gert Taaibosch, Gert Lynx and Piet Witvoet, alias 'Wicked Pi' - lived in more or less neighbourly peace with people who formerly had cause to dread their very names. 
Moletsane, companion of Sebetwane during his early career, survived under Moshweshwe's protection, still scheming to rebuild a Taung kingdom stretching beyond the Sand River. Moroka, chosen chief of the Rolong at Thaba Nchu had likewise survived the alleged holocaust. Missionaries British, French and German - had by this time planted themselves near all the major chiefs of the region.

It beggars belief that in five years between 1828 and 1833 communities decimated by war, drought and famine had reconstituted themselves in numerous prosperity and that practically the whole front rank of chiefly leadership survived. Even if Ellenberger's supposed 300,000 victims of cannibalism had all been males who left pregnant females behind, it is impossible to explain the miraculous population recovery. No account mentions disproportionate numbers of young children. People who had heard the legend before travelling to the interior were astonished to find so many people flourishing in lands which contemporary maps depicted as 'depopulated by the Zulu wars'. French hunter/naturalist, Adulphe Delegorgue, who toured the eastern highveld in the early 1840s, was flabbergasted to find that Sotho peoples supposedly massacred by Shaka, Dingane and Mzilikazi had spread themselves thickly over a landscape extending two hundred leagues between Potchefstroom and the Drakensberg.xxxv Forced to choose between the legend of devastation and 
eyewitness accounts of numerous populations, historians should discard the legend. That raises the question of why the legend arose in the first place.

\section{STRUGGLES FOR LAND AND LEGITIMACY}

In the pre-colonial economy, the strength of chieftainship depended on control of people. Rival chiefs competed to attract followers. So it had been with Sekonyela, Moshweshwe and other aspirants to power in the Caledon valley. They encouraged newcomers to live under their protection. Everything changed with the advent of Boer land seekers. Ownership of land became all important when Boers began claiming that they had purchased land from chiefs. From the moment H. D. Warden took up his post as British Resident at Bloemfontein in January 1846, his office was flooded with missionaries' letters asserting the land claims of competing chiefs. With no knowledge of the Sotho language he relied on interpreters and letters written in English to arrive at conclusions about who owned the land. Missionaries wrote most of the letters on behalf of chiefs under whose protection they lived. Their reports naturally reflected the current political 
realities. These shifted from time to time, as can be seen using the examples of Moshweshwe and his great rival, Sekonyela.

In 1835 Moshweshwe told Andrew Smith that his people, 'the Basuto were originally Baquaina' from the northern Transvaal, who had 'left the country of their forefathers in consequence of oppression and poverty.' Their 'present country' he identified as 'the third which they have occupied since they became emigrants'. Their initial move had been to the vicinity of the Likwa River (the Vaal), the second to the 'sources of the Caledon' and their third to their present position surrounding Moshweshwe's stronghold of Thaba Bosiu following attacks by the Hlubi, Ngwane and Tlokwa. xxxvi Sekonyela's famous mother, MaNthatisi told Smith that they had recently moved from the relatively close Namahari (Wilge) River where their people had lived from time immemorial.xxxvii

By 1842, when the Cape Governor, George Napier, was seeking treaties with important chiefs, missionaries told quite different stories. A memorial from the Paris Evangelical Society missionaries with Moshweshwe claimed all the land from the Caledon to the Orange, explaining that under his leadership thirty to forty thousand Basuto people had found protection from the attacks of Matiwane and Mpanganzitha in the 1820s. John Philip of the London Missionary Society, a denominational ally of the French Calvinists, supported their claims, and argued that among all the chiefs of the Caledon, only Moshweshwe 
deserved recognition through a British treaty. ${ }^{x x x v i i i}$ Methodist missionary superintendent William Shaw had quite a different tale to tell when seeking treaties for groups allied in one way or another with the Methodists. He had been assured by the chiefs of the Rolong, Griquas and Kora that when they migrated to empty lands on the right bank of the Caledon, Moshweshwe had 'gladly entered into arrangements with them, recognising their title to these lands, in consideration mainly of the protection which he hoped to receive from the residence of a powerful body of people friendly to him, and who had already become possessed of firearms, for at that time he was living in great fear from the hostility of the Zulus'. Sekonyela, according to Shaw, also deserved a British treaty. ${ }^{x x x i x}$

In light of these claims and counter-claims French missionary, Eugène Casalis, was at pains to explain in 1844 that earlier reports of widespread depopulation should not be read as an indication that the land had been emptied of inhabitants. There were, he affirmed, no less than 189 well-established Basuto villages under Moshweshwe, whose inhabitants were the original possessors of the land. ${ }^{x l}$ Whereas he had previously exulted that he and his fellow missionaries had brought peace to a blood-stained desert, he now asserted that Moshweshwe commanded a following of tens of thousands of people with an undoubted right to the land. In 1845, Moshweshwe purported to speak for himself (through a 
French missionary's transcription of his words) about contested land. ${ }^{x l i}$ Prior to 1818, he asserted, the whole region had been 'exclusively known and owned by the Mayaiyana, the Makhoakhoa, the Bamonangeng, the Barmokheli, the Batele or Batlakoana, and the Baphuti. These tribes went by the general name of Basutos, spoke one language, had the same habits and customs, intermarried, and considered each other as having had, at some remote period, one common origin.' In this account there was no mention of any northern homeland or routes of migration. Contrary to other accounts which say he migrated to the stronghold of Bute Bute in 1820, he refers to 'Butabute' as his 'birthplace'. While admitting that his people had traded with the Tlokwa, he utterly denied that their leaders had ever occupied land in the Caledon. MaNthatisi and her son Sekonyela had suddenly appeared soon after 1820. As for the Griqua and Kora, he claims never to have had heard of either group until they 'began a regular system of depredation against my people.' He likewise claims to have had no previous idea that white people or firearms existed. Whether or not this was true, it made a first-rate defence against the claims by Griqua and Kora captains that Moshweshwe had actively sought their settlement among his people. As for his own following, he reckoned that there may have been 50,000 Basutos in 700 villages. On his part Sekonyela argued that he had held and lived on his extensive lands since 1820, and accepted 
no part of Moshweshwe's claim to primordial chieftainship, treating him as another conqueror like himself. $x$ lii

British officials took these arguments with a grain of salt. After listening to all the conflicting stories, Cape Governor Peregrine Maitland concluded in December 1845 that 'there is scarcely a tribe in all these regions which inhabits its own hereditary soil; almost all are but new occupants of their present abodes.'xliii Warden, the newly appointed British Resident, believed that 'if the right of conquest be recognized, a great part of the disputed country would fall to the lot of Sikonyela'. xliv By 1850 Warden had joined a coalition of all Moshweshwe's enemies and was planning an attack with an allied force including 'a force of 1000 of Moroko's Barolongs, 600 of Sikonyela's Tloka, 300 of Adam Kok's Griquas and 150 of Waterboer's, 200 of Gert Taaibosch's Koranna.' Captain Jan Bloem, Warden added, 'could also give a large contingent, with the Boers mustering about 300.'xlv Though his assault turned into a farcical defeat, as a consequence of Warden's manoeuvres all the Caledon leaders had a heightened sense of the importance of securing British endorsement of their land claims. The most spectacular convert to negotiation was Sekonyela, previously regarded by both missionaries and officials as a recalcitrant and aggressive presence. Methodist William Shaw reported in October 1851 that 
The Chiefs and Tribes of Moroko, Gert Taaibosch, Sikonyela, and the Bastards under C. Baatje, with the Fingos of Umpukani, are all united by close alliance and friendship, - it is amongst these tribes chiefly that the Wesleyan Missions are established, and the whole of these tribes are now and always have been on the most friendly terms with the British Government. At one time Sikonyela gave some trouble, but he soon submitted himself to the Government, although he and his people (Mantatis) have been heretofore among the most active and brave of all the Native Tribes in that part of the country. ${ }^{.1 v i}$

This, then, was the situation when the British government suddenly decided to withdraw from the highveld and appointed a new governor, George Cathcart, to make arrangements for a handover of sovereignty to local authorities. On one side stood the Methodist missionaries and their allies. On the other stood the French missionaries and Moshweshwe's following.

With the whole Caledon Valley at stake in 1852, the competing parties carefully crafted submissions supporting their land claims. Moshweshwe now presented himself as sole heir to a line of landholders extending indefinitely into the past. Was it his fault, he asked, if 'he, and Mokochane his father, and Pete his grandfather, and Matie his great grandfather, were born in this country?'xlvii Was it the fault of him or 'his missionaries, if Moroko and Gert Taaibosch were born 
and have grown in the Vaal River district some 300 miles from the country of the Basutos; C. Baatje in the Colony; P. Davids in Namaqualand; and Sikonyela on the sources of the Vaal?' Moletsane, who had once pursued a career of conquest on the western highveld but had now become a loyal henchman to Moshweshwe, presented himself as an innocent victim of alien marauders. ${ }^{\text {lviii }}$ 'Towards the years 1822-23' he recalled, 'political commotions took place among the Zulus of Natal. Msilikazi was obliged to leave that country on account of the cruel proceedings of the Inkosi Tshaka. He passed the Quatlamba Mountains, devastating all before him. Other Chiefs, as Matiwana and Pakalita, followed his example, and fell on the neighbouring tribes.' Although this reversed accounts which blamed Mpanganzitha and Matiwane for upsetting the primordial peace on the highveld, that did not concern Moletsane, whose primary aim was to conceal his own youthful transgressions. He presented himself as the champion of 'the Lighoyas under the Chief Gassapiane', who, 'having been robbed of their cattle by the Barolong' called Moletsane to their assistance'. It was, he continued 'at this time that the friend and ally of Molitsane, Sebetoane, who is now residing near the great lake Ngami, was also subverting the interior. It was the dreadful Msilikazi who forced Sebetoane to go towards the lake and at the same time Molitsane to retreat to the Vaal River, from whence he made several successful incursions against Msilikazi, who sent his frightful legions against the Bataung and made awful havoc among them.' On the basis of his descent and his sufferings, Moletsane laid claim to a large tract between in the Sand River 
region. xlix Moroka, chief of the Barolong settlement at Thaba Nchu, defended his claim to land on the basis of the assistance he had rendered to the Boers in their campaigns against the Ndebele and his steadfast loyalty to the British after the proclamation of the Orange River Sovereignty. ${ }^{1}$ The lesser leaders of Caledon Valley groups put forward their own self-serving accounts of victimhood and land rights.

General Cathcart dismissed all these narratives as a pack of lies. They were, he said 'the production of certain missionaries' and were 'generally closed by a cross superscribed as the Chief $\mathrm{X}$ his mark.' Although he had read them with 'much interest' he could only conclude that 'in respect to their value as official documents I can only consider them in the light of political frauds.'li The most meaning he ventured to extract from the conflicting accounts was that when the Boers arrived they walked into an arena of internecine African warfare 'of more than ordinary rancour, and as it is described in their own language, eating each other up, - an expression even then not merely metaphorical, as some of them are said to have been cannibals.' lii As far as he could see, Moshweshwe had become a 'centre of aggregation' whose expansive intentions needed to be countered.

He then proceeded to engage Moshweshwe in battle with the aim of ensuring that Britain's withdrawal occurred with no loss of face. Though the battle was inconclusive, Moshweshwe's tactful submission paved the way for Cathcart's evacuation of his forces. As soon as he could marshal his own troops 
the king launched a decisive assault on all his old enemies in 1853. When the dust had cleared, only Moroka's Rolong at Thaba Nchu maintained their position. Sekonyela, along with the Griqua and Kora captains were swept away forever.

While these facts are well known, their effect on the writing of precolonial history has not been generally recognised. Every claim for land in the Caledon had been based on a self-interested version of events in the 1820s, a period conveniently just beyond the reach of written documentation. Every party to the disputes had reason to exaggerate the level of violence and political upheaval in that period. Colonial officials inherited from the Scottish Enlightenment a theory of historical evolution which held that in the 'barbarous state', chiefs of 'warlike and turbulent spirit' resorted to 'the bridle of despotism and military force' to make their way in the world. . $^{\text {iii }}$ French missionaries relished the idea that their influence had brought peace to a war-torn land. As one of them wrote, 'From the time of the arrival of the missionaries among the Mantetis and the Basutos, the population of the country began to increase, through their endeavours to put an end to cannibalism, one of the most active causes of depopulation.' 'liv Boer trekkers had an interest in portraying the entire highveld (and Natal) as virtually cleared of original owners, thus putting themselves on the same level as other parvenus. Sekonyela, Moroka, Moletsane and the lesser Griqua/Kora captains along with the Methodist missionaries who wrote down their submissions hoped to win sympathy for their plight as refugees fleeing from a maelstrom of highveld violence and merciless invaders from Zululand. After Moshweshwe 
had swept his enemies away, the version of history agreed on by him and the French missionaries went largely unchallenged. J. M. Orpen, who took up the Basotho king's cause in opposition to the Free State Boers in the 1850s solidified the story in his History of the Basutos (1857), quoted above.

Sharp-eyed readers will have already noticed that most of the footnotes to this article refer to the first volume of G. M. Theal's Basutoland Records (1883), which was produced with official sponsorship not long after the British annexation. It stands alongside the French missionary archive as the fullest documentary record of the early nineteenth century. It enshrined the pleadings of land claimants as enduring witnesses to history 'as it really happened'. Thanks to their narratives, what had been a storm in the teapot of the Caledon Valley was generalised to a cyclone engulfing the whole of southeast Africa. Taken together with the wild generalisations about Shaka's conquests penned by H.F. Fynn and other early Natal traders, it laid the basis for all subsequent accounts of the mfecane.

That is almost, but not quite the end of the story. Even before Theal's Records appeared, G. W. Stow noticed that BaSotho oral history was an evolving narrative, not a fixed tradition. 'Even those native authorities of the present day who profess that they have preserved some portion of the history of their tribes have so mutilated and adulterated the traditions, modifying them to suit the altered conditions of the nation or tribe to which they belong, that the originality and authenticity of these narrations have at length in many instances become so 
completely obscured or destroyed that they are rendered nearly valueless ....'lv To illustrate his point Stow pointed to discrepancies between accounts recorded in the 1830s and the testimony of Moshweshwe's son, Nehemiah in 1880. 'The statements of Nehemiah', he noted, 'evidently embody all the additions and modifications which have been made to the original tribal history. This tampering has been clearly intended to show that from the commencement Moshesh had a rightful claim, both by descent and inheritance, to the paramount chieftainship of the Basutu nation, as well as to the territory over which he subsequently attempted to exercise sovereignty.' It was this same Nehemiah who first defined 'faqane' a Sotho word from which the Zulu-ized term mfecane may have been derived:

The name of Faqane refers to people who attack not while staying in their own villages, those who are travelling with everything they own, cattle, women, children, those who began to go in that way . . . we have just described, being the Mankoane [AmaNgwane], Mahluibi [AmaHlubi], Sekonyela and the Basiea [BaSia], all those who feared Chaka; it was in reference to them the name of Faqane appeared..$^{\mathrm{vi}}$

Stow's observation on the way history was crafted to serve the house of Moshweshwe can be extended. The legend of an awful time - the lifaqane - when the founder threw the cloak of his protection over many shattered peoples aided 
in the king's calculated obliteration of the memory of the chiefs he had usurped. In the normal course of events, chieftainship would have been passed down in the line of Monaheng, father of Mohlomi and Makheta. At Mohlomi's death Makheta assumed the mantle. As late as 1827 a man accompanying a raid into Xhosa territory told a British interrogator that he came from 'the other side of the Great (Orange) River, our people consist of two tribes, formerly distinct, "Masotu" and "Manguana", our great chiefs are Maketa and Mattuana [Matiwane].' 'vii It seems likely that the term Makatis, applied to Sotho migrant labourers in the Cape Colony was derived from Makheta rather than being a variation on Mantatees. ${ }^{\text {lviii }}$ Makheta had done all he could to stave off Moshweshwe's challenge, including a brief alliance with Sekonyela and summoning Kora gunmen to assist him. lix On his part Moshweshwe repeatedly attacked the man he is reported to have called 'cousin' or 'uncle' until he had succeeded in destroying his power. ${ }^{\mathrm{lx}}$ With French missionary scribes on hand to record their words, members of the house of Moshweshwe made a new history which emphasised the founder's links to Mohlumi and all but purged Makheta from the record. At the same time the missionaries collaborated in a tale of how they and their protector had brought peace to a land torn with strife and cannibalism.

Julian Cobbing called the mfecane an alibi for slavers and settlers. It might more appropriately be termed an alibi for African land seekers and the founder of the kingdom of Lesotho. 


\section{CONCLUSION}

The extent of death and violence that may have occurred on the highveld and lowveld of South-Eastern Africa in the 1820s cannot be documented using historical records. Previous estimates have relied on: 1) fragmentary records of conflict among Tswana and Griqua/Kora groups in the western zone; 2) reports by traders and Shaka's African enemies about the 'depopulation' of Natal; and 3) recorded statements from leaders of Caledon Valley political groupings in the period 1833-54. Apart from eye-witness accounts of the 'Battle of Dithakong', there are few reliable body counts of deaths in the western highveld. The work of John Wright has exposed fatal flaws in the old picture of a Natal devastated by Shaka's murderous armies. ${ }^{1 \times i}$ The remaining documentation comes from competing claimants for land in the Caledon River region, a relatively small part of Southern Africa. It is too tainted by self-interest and contradictions to form the basis for accurate estimates of violence. Slaving in Mozambique in the 1820s and ‘30s must have generated a great detail of suffering which cannot be quantified. For practically all the rest of Southern Africa the historical record is silent. While there were undoubted movements of Nguni warrior bands away from Zululand, historians have no way of estimating the amount of death or disruption they may have caused. Under the circumstances it would be wise to maintain an agnostic stance on 'mfecane violence' and its consequences. 


\section{NOTES}

i Julian Cobbing, 'The Mfecane as Alibi: Thoughts on Dithakong and Mbolompo', Journal of African History 29 (1988) 487-519;

Elizabeth Eldredge, 'Sources of Conflict in Southern Africa, c. 1800-

30. The "Mfecane" Considered', Journal of African History 33 (1992):

1-35; Carolyn Hamilton, "'Character and Objects of Chaka". A Reconsideration of Shaka as Mfecane Motor', Journal of African History 33 (1992), 141-57.

ii Carolyn Hamilton, ed., The Mfecane Aftermath: Reconstructive Debates in Southern African History (Johannesburg, 1995).

iii John Wright noticed this in 'Mfecane Debates, Southern African Review of Books, 39/40 (1995), 18-19.

iv Elizabeth Eldredge and Fred Morton, Slavery in South Africa: Captive Labour on the Dutch Frontier (Pietermaritzburg, 1994), especially chapter 5.

v Simon Hall, 'Archaeological Indicators for Stress in the Western Transvaal Region between the Seventeenth and Nineteenth Centuries' in Mfecane Aftermath, 307-21. Interestingly, the Lepalong cavern complex, which is the subject of Hall's research, appears to be marked on Adulphe Delegorgue's map drawn in the 1840s, showing near 'Zuiker-Bosch-Rand', a 'caverne où vivaient 
3000 Cafres Makatisses, Appelés Gat.s s Caffers' [cavern where 3000 Makatis used to live, called Gat's Kaffirs]; Voyage dans l'Afrique Australe (Paris, 1847), 'Carte pour l'intelligence du Voyage Dressé par Adulphe Delegorgue'.

vi Comment of Terence Ranger recounted by Julian Cobbing, personal communication.

vii G, M. Theal, History of South Africa 1795-1834 (London, 1891) facing 328. See also Christopher Saunders, The Making of the South African Past (Cape Town, 1988), 41.

viii Eric Walker, A History of Southern Africa (first published 1928; London, 1962), 175-76. However, Walker dismissed Theal's claims of 'depopulation'.

ix Martin Legassick, 'The Griqua, the Sotho-Tswana and the Missionaries, 1780-1840' (Ph.D. thesis, UCLA 1969), appendix of maps.

x John Omer-Cooper, The Zulu Aftermath (London, 1966).

xi George W. Stow, 'The Intrusion of the Stronger Bantu Races', unpublished mss., 1880, Stow Collection; South African National Library, Cape Town, II, 48-49; William Lye and Colin Murray, Transformations on the Highveld: the Tswana and Southern Sotho (Cape 
Town, 1980), 38; Robert Ross, Adam Kok's Griquas: a study in the development of stratification in history (Cambridge, 1976), 27. xii John Centilvres Chase, ed. The Natal Papers: A Reprint of all Notices and Public Documents Connected with that Territory , 2 vols. in one. (Grahams Town, 1843, reprint ed. Cape Town, 1968), 20. xii G. M. Theal, History of the Boers in South Africa (first published 1887, reprinted Cape Town, 1973), 34; Cobbing, 'The Mfecane', 315; Saunders, 'Pre-Cobbing Mfecane Historiography', 23. On Theal's career see Christopher Saunders, The Making of the South African Past (Cape Town, 1988), 9-29.

xiv D. Fred. Ellenberger, History of the Basuto, Ancient and Modern (London, 1912), 225, 303. A similarly reckless calculation was made by Methodist missionary John Ayliff who reckoned that 'Shaka killed 690,000 Fingo'; see Alan C. Webster, "Land Expropriation and Labour Extraction under Cape Colonial Rule: the War of 1835 and the 'Emancipation' of the Fingo" (M.A. thesis, Rhodes University, 1991), 19.

xv W. M. Macmillan, Bantu, Boer and Briton: The Making of the South African Native Problem (London, 1929), ix, 18-20; John W. Cell, The Highest State of White Supremacy: the Origins of Segregation in South Africa and the American South (Cambridge, 1982), 100; William F. Lye 
and Colin Murray, Transformations on the Highveld: the Tswana and Southern Sotho (Cape Town, 1980), 30-31, 58.

xvi Hannah Arendt, The Origins of Totalitarianism (London, 1973), 192. The citation has not changed through many editions since first publication in 1951.

xvii Dan Wylie, Savage Delights: White Myths of Shaka (Pietermaritzburg, 2000), 194.

xviii Chase, Natal Papers, II, 76-77

xix John Campbell, Travels in South Africa (London, 1822, reprinted in one vol. New York, 1967), 174, 127, 232-32, 314, 157, 126, 224, 78, 100, 231-32. This was his second journey; he had made a previous, less extensive survey in 1814.

xx Neil Parsons, A new History of Southern Africa (London, 1982), 4550. xxi J. P. R. Wallis, ed., The Matabele Journals of Robert Moffat, 18291860, 2 vols. (London, 1945) I, 57; S. M. Molema, Chief Moroka (Cape Town, n.d.), 1-2; William Lye, 'The Sotho Paramount Chief and the Difaqane', paper presented to the 14th meeting of the African Studies Association, Denver, 1971, 8. xxii Peter Delius, The Land Belongs to Us: the Pedi Polity, the Boers and the British in the Nineteenth-century Transvaal (London, 1984), 12-13; 
H. O. Mönnig, The Pedi (Pretoria, 1967), 19-20; Lye, 'the Sotho Paramount Chief', 8-9; Andrew Manson, 'Conflict in the Western Highveld', in Mfecane Aftermath, 352-53.

xxiii T. Arbousset and F. Daumas, Narrative of an Exploratory Tour to the North-East of the Colony of the Cape of Good Hope, trans. John C. Brown (Cape Town, 1846; reprinted Cape Town, 1968), 273;

Ellenberger History of the Basuto, 94, dates this journey to 'cannibal' territory to about 1782 .

xxiv Alan Smith, 'The Struggle for Control of Southern Mocambique' (Ph.D. thesis, UCLA., 1970), 68; see also Malyn Newitt, History of Mozambique (London, 1995), 247-48.

xxv J. M. Orpen, History of the Basutus of South Africa (Cape Town, 1857), 6.

xxvi Eugène Casalis, The Basutos or Twenty-Three Years in South Africa (London, 1861),16-17.

xxvii Stow, 'Intrusion of the Stronger Bantu Races', II, 256-57.

xxviii Beginning with Ellenberger, History of the Basuto, and carrying through to Lye and Murray, Transformations, 124-27. xxix Robert Moffat, Missionary Labours (London, 1842), 523-28. xxx Claude Fuller, Louis Trigardt's Trek across the Drakensberg, 18371838, ed. Leo Fouché (Cape Town, 1932) Neither did Tregardt meet 
encounter any Ndebele or Zulu regiments; only when he crossed into the lowveld did he encounter a challenge from 'Ngoni' (a word which the editor renders as 'Zulu'),130-33.

xxxi Arbousset and Daumas, Narrative, 66;

xxxii Orpen, History of the Basutus, 6. George M. Theal, ed. Basutoland Records (Cape Town, 1883), I, 109.

xxxiii John Wright and Andrew Manson, The Hlubi Chiefdom in

Zululand-Natal: A History (Ladysmith, 1983), 20.

xxxiv Basutoland Records, I, 51, 108-09; William Cornwallis Harris, The

Wild Sports of Southern Africa (first published 1837; fifth ed.

reprinted Cape Town, 1963), 119-20; Arbousset and Daumas,

Narrative, 210, 226.

xxxv Delegorgue, Voyage, II, 323.

xxxvi Andrew Smith's official report, 1836, printed in Basutoland

Records, I, 9.

xxxvii Ibid., 13.

xxxviii Basutoland Records, I, 43-47.

xxxix William Shaw to the Secretary to Government, 15 Dec. 1843, in Basutoland Records, I, 57.

xl Casalis to Civil Commissioner of Colesberg, 19 Mar. 1844, in Basutoland Records, I, 65-66. 
xli Moshesh to Sec to Govt., Thaba Bosigo, 15 May 1845 in

Basutoland Records, I, 82-86 (with original italics).

xlii Basutoland Records, I, 194.

xliii Sir P. Maitland to Lord Stanley, 1 Aug. 1845, in Basutoland

Records, I, 93-101.

xliv Warden to Maitland, 11 Mar. 1846, in Basutoland Records, I, 120-

21.

xlv Warden to Sec to High Commissioner, 10 Nov. 1850, in

Basutoland Records, I, 348.

xlvi Shaw to Hogge, 20 Oct. 1851, in Basutoland Records, I, 459-60.

xlvii Basutoland Records, I, 499-516.

xlviii Statement drawn up at the request of the Chief Molitsane,

Mekuatling, Jan. 1852, in Basutoland Records, I, 517-19.

xlix Ibid, 531.

${ }^{1}$ Moroko's Memorial to High Commissioner Cathcart, in Basutoland

Records, I, 579-80.

li Cathcart to the British Resident, [Henry Green] 2 Sept. 1852, in

Basutoland Records, I, 587.

lii Cathcart to Sec. of State for Colonies. 14 Nov. 1852, in Basutoland

Records, I, 604-608. 
liii Adam Ferguson, Essay on the History of Civil Society (1767) and J. Millar, The Origin of the Distinction of Ranks, quoted by Jeremy Martens in 'The Impact of Theories of Civilization and Savagery on Native Policy in Colonial Natal', (unpublished paper written for a forthcoming collection, Zulu Enigmas).

liv Arbousset and Daumas, Narrative, 54.

lv George W. Stow, The Native Races of South Africa, ed., G. M. Theal (London, 1905), xi-xii. Stow's manuscript was penned before his death in 1882, but not published until 1905. Stow's observation that the Sotho were the inventors of their own traditions reinforces the point recently made by Tom Spear that 'far from being created by alien rulers ... tradition was reinterpreted, reformed and reconstructed by subjects and rulers alike; 'Neo-Traditionalism and the Limits of Invention in British Colonial Africa', Journal of African History 44 (2003), 4.

lvi Translation by Elizabeth Eldredge in Elizabeth Eldredge, "Migration, Conflict and Leadership in Early 19th Century South Africa. The Case of Matiwane". Seminar paper, Dept of History Univ. of Natal, Durban, 3 August 1994, 8. Ellenberger used the word throughout his History of the Basuto, see, for example, 38, 48, $52,217$. 
lvii W. M. Mackay to Sec. To Govt. Somerset 8 Aug. 1827, in N J

Van Warmelo, ed., History of Matiwane and the Amangwane Tribe, as told by Msebenzi to his kinsman Albert Hlongwane. Pretoria, 1938),

235-36. The same account with different spelling appears in South African Archival Records, Important Cape Documents, Vol 4: Records of Natal, 1823-August 1828, ed. B. J. T. Leverton (Pretoria, 1984), 132-35.

lviii Basutoland Records, I, 517-19;

lix Ellenberger, History of the Basutos, 153; Arbousset and Daumas, Narrative, 310; Delegorgue, Voyage II, 323-4, 461.

lx Elleberger, History, 153; Arbousset and Daumas, Narrative, 30001,310 .

lxi 'Contrary to the commonly held view, these groups used force not so much to wipe out populations as to seize the resources and, at times, to destroy the political organization of communities which stood in their way .... Many, probably most, of their members, though, survived to give their allegiance, either as individuals or in groups, to other chiefs.' John Wright, 'Political Transformations in the Thukela-Mzimkhulu Region in the Late Eighteenth and Early Nineteenth Centuries', in Mfecane Aftermath, 175.' 